\title{
Development of soil test crop response based fertilizer prescriptions through integrated plant nutrition system for aggregatum onion (Allium cepa L.) under drip fertigation
}

\author{
M. Parvathi Sugumari* \\ Department of Soil Science and Agricultural Chemistry, Tamil Nadu Agricultural University, \\ Coimbatore (Tamil Nadu), India \\ S. Maragatham \\ Department of Soil Science and Agricultural Chemistry, Tamil Nadu Agricultural University, \\ Coimbatore (Tamil Nadu), India

\section{R. Santhi} \\ Department of Soil Science and Agricultural Chemistry, Tamil Nadu Agricultural University, \\ Coimbatore (Tamil Nadu), India

\section{R. Swarna Priya} \\ Department of Vegetable Science, Tamil Nadu Agricultural University, Coimbatore (Tamil \\ Nadu), India \\ * Corresponding author. Email: parumeenakshi.acre@gmail.com
}

\section{Article Info}

https://doi.org/10.31018/

jans.v13i3.2907

Received: August 05, 2021

Revised: September 8, 2021

Accepted: September 12, 2021

\section{How to Cite}

Parvathi Sugumari, M. et al. (2021). Development of soil test crop response based fertilizer prescriptions through integrated plant nutrition system for aggregatum onion (Allium cepa L.) under drip fertigation. Journal of Applied and Natural Science, 13 (3), 1094 - 1101. https://doi.org/10.31018/jans.v13i3.2907

\begin{abstract}
An insight into the balanced crop nutrition and efficient irrigation will be rewarding to attain profitable bulb yield of shallow-rooted and high nutrient requiring aggregatum onion. To develop fertilizer prescription equations(FPEs) for aggregatum onion under drip fertigation by encompassing the Soil Test Crop Response approach (STCR), a field experiment was conducted in Palaviduthi soil series with 15 treatments viz., Absolute control $\left(T_{1}\right)$, Blanket recommendation (60:60:30) + Farm Yard Manure (FYM) @ $12.5 \mathrm{t} \mathrm{ha}^{-1}\left(\mathrm{~T}_{2}\right)$, STCR based NPK fertilizer recommendation (STCR-NPK) for the targeted yield of $14\left(\mathrm{~T}_{3}\right), 15\left(\mathrm{~T}_{4}\right), 16 \mathrm{t} \mathrm{ha}{ }^{-1}$ $\left(T_{5}\right)$, FYM @ $6.25\left(T_{6}\right), 12.5 \mathrm{t} \mathrm{ha}^{-1}\left(\mathrm{~T}_{7}\right), \mathrm{STCR}-\mathrm{NPK}+\mathrm{FYM} @ 12.5 \mathrm{t} \mathrm{ha}^{-1}$ for the targeted yield of $14\left(\mathrm{~T}_{8}\right), 15\left(\mathrm{~T}_{9}\right), 16 \mathrm{t} \mathrm{ha} \mathrm{H}^{-1}\left(\mathrm{~T}_{10}\right)$, Biocompost @ $2.5\left(T_{11}\right), 5 \mathrm{t} \mathrm{ha}^{-1}\left(\mathrm{~T}_{12}\right)$ and STCR-NPK+Biocompost @ $5 \mathrm{t} \mathrm{ha} \mathrm{a}^{-1}$ for the targeted yield of $14\left(\mathrm{~T}_{13}\right), 15\left(\mathrm{~T}_{14}\right), 16 \mathrm{t} \mathrm{ha}{ }^{-1}$ $\left(T_{15}\right)$. The results revealed that $T_{10}$ was more supercilious than others. The basic parameters were deliberated from the experimental data on total nutrient uptake, initial soil fertility status, applied fertilizer doses. The aggregatum onion (variety $\mathrm{CO} 4$ ) required $0.43,0.32,0.45 \mathrm{Kg}$ of $\mathrm{N}, \mathrm{P}_{2} \mathrm{O}_{5}, \mathrm{~K}_{2} \mathrm{O}$ to produce one quintal of bulb yield. The percent contribution of nutrients from soil and fertilizer was $14.01,54.57$ for $\mathrm{N}, 35.11,50.50$ for $\mathrm{P}_{2} \mathrm{O}_{5}$ and $12.69,70.12$ for $\mathrm{K}_{2} \mathrm{O}$, respectively. The contribution of $\mathrm{N}, \mathrm{P}_{2} \mathrm{O}_{5}$, $\mathrm{K}_{2} \mathrm{O}$ from $\mathrm{FYM}$ and biocompost were 41.02, 16.23, 41.53 and 47.98, 15.87, 49.56 percent sequentially. Based on the above parameters, the fertilizer prescription equations were formulated for aggregatum onion under drip fertigation in Palaviduthi soil series.
\end{abstract}

Keywords: Aggregatum onion, Drip fertigation, Fertilizer prescription equations, STCR - IPNS

\section{INTRODUCTION}

Aggregatum onion (Allium cepa var. aggregatum), belonging to the Alliaceae family portrayed as "Queen of the kitchen" is one of the most important commercial bulb vegetables. India is the second-largest producer next to China with cultivating area, production and productivity of 1.43 million hectares, 26.15 million tonnes and 18.3 $\mathrm{MT}^{\text {ha }}{ }^{-1}$, respectively. In Tamil Nadu, it is cultivated over an area of 0.27 lakh hectares and production of 3.11 lakh tonnes during 2017-2018 (https://www.indiastat.com/agriculture-data.aspx). The existence of allyl propyl disulphide makes onion having an idiosyncratic pungent taste.

The foremost things to be appraised for escalating high yield are optimum irrigation and balanced fertilization since it is a shallow-rooted and high nutrient requiring crop. This can be achieved in a better manner by the 
adoption of the soil test crop response approach as described by Ramamoorthy et al. (1967) and drip fertigation (Solanki et al., 2020). Soil test based fertilizer recommendation harmonizes the much debated approaches namely "Fertilizing the soil" versus "Fertilizing the crop" guaranteeing a real balance between the applied and soil available nutrients (Vijayakumar et al., 2017). It is a demand-driven technology that allows farmers to choose yield targets based on resource endowment capacity and farm typology, thereby using the plant nutrients judiciously.

Although there is a fast retrieval of nutrients from inorganic fertilizers, utilization of organic manures and them that is inorganic manures meet crop nutrient requirements will be an inevitable practice to augment sustainable agriculture consecutively upgrading crop productivity and quality in the near future (Adekiya et al., 2020). So, the integrated plant nutrition system will be a significant option for cost-effective sustainable management of soil fertility. With this view, Fertilizer Prescription Equations (FPEs) were developed for aggregatum onion under soil application by Santhi et al. (2002), adopting STCR - IPNS approach.

The rising demand for water supply exerts tremendous pressure on agricultural sectors to use available water efficiently to meet future needs. Onion requires frequent but not heavy irrigations as sufficient soil moisture is crucial for bulb development which is greatly influenced by the irrigation system (Bhasker et al., 2018). Drip irrigation is of pressing priority to assure commercial agriculture's economic and environmental sustainability (Mebrahtu et al., 2019).

By conjoining these as drip fertigation, fertilizers and water can be released directly to the immediate vicinity of the root zone during peak crop demand that can minimize losses and treble the yield of crops (Ramadaas et al., 2017). In this context, this study was contemplated to develop the fertilizer prescription equations for aggregatum onion (Allium cepa L.) under drip fertigation for Palaviduthi soil series. This study also ensures as a guideline for achieving desired targeted yield in aggregatum onion.

\section{MATERIALS AND METHODS}

\section{Experimental site and initial soil description}

The field experiment was conducted in a farmer's field in Kuppanur village of Thondamuthur, Coimbatore where aggregatum onion (variety $\mathrm{CO} 4$ ) was sown during rabi (2020). The experimental field's soil was categorized under Palaviduthi soil series, red, noncalcareous, sandy loam (Typic Rhodustalf) with $\mathrm{pH} 7.4$ and EC $0.15 \mathrm{dSm}^{-1}$. The initial fertility status was low in organic carbon $(0.47 \%)$ and available nitrogen $(196 \mathrm{Kg}$ $\mathrm{ha}^{-1}$ ), high in available phosphorus (35 Kg ha $\left.{ }^{-1}\right)$, medium in available potassium $\left(250 \mathrm{Kg} \mathrm{ha}^{-1}\right)$.

\section{Treatment details}

The experiment was laid out in a Randomized Block Design with three replications consisting of 15 treatments viz., $\mathrm{T}_{1}-$ Absolute control, $\mathrm{T}_{2}-$ Blanket fertilizer recommendation (60:60:30) + FYM @ 12.5 t ha $^{-1}, \mathrm{~T}_{3}-$ STCR based NPK fertilizer recommendation for the targeted yield of $14 \mathrm{t} \mathrm{ha}^{-1}, \mathrm{~T}_{4}-$ STCR based NPK fertilizer recommendation for the targeted yield of $15 \mathrm{t} \mathrm{ha}^{-1}$, $\mathrm{T}_{5}$ - STCR based NPK fertilizer recommendation for the targeted yield of $16 \mathrm{t} \mathrm{ha}^{-1}, \mathrm{~T}_{6}-\mathrm{FYM} @ 6.25 \mathrm{t} \mathrm{ha}^{-1}$, $\mathrm{T}_{7}$ - FYM @ $12.5 \mathrm{t} \mathrm{ha}^{-1}, \mathrm{~T}_{8}-$ STCR based NPK fertilizer recommendation + FYM @ $12.5 \mathrm{t} \mathrm{ha}^{-1}$ for the targeted yield of $14 \mathrm{t} \mathrm{ha}^{-1}, \mathrm{~T}_{9}-$ STCR based NPK fertilizer recommendation + FYM @ $12.5 \mathrm{t} \mathrm{ha}^{-1}$ for the targeted yield of $15 \mathrm{t} \mathrm{ha}^{-1}, \mathrm{~T}_{10}-\mathrm{STCR}$ based NPK fertilizer recommendation + FYM @ $12.5 \mathrm{t} \mathrm{ha}^{-1}$ for the targeted yield of $16 \mathrm{t} \mathrm{ha}^{-1}, \mathrm{~T}_{11}$ - Biocompost @ $2.5 \mathrm{t} \mathrm{ha}^{-1}, \mathrm{~T}_{12}-$

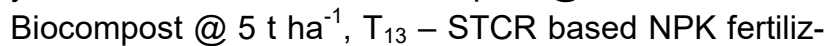
er recommendation + Biocompost @ $5 \mathrm{t} \mathrm{ha}^{-1}$ for the targeted yield of $14 \mathrm{t} \mathrm{ha}^{-1}, \mathrm{~T}_{14}-\mathrm{STCR}$ based NPK fertilizer recommendation + Biocompost @ $5 \mathrm{t} \mathrm{ha}^{-1}$ for the targeted yield of $15 \mathrm{t} \mathrm{ha}^{-1}, \mathrm{~T}_{15}-\mathrm{STCR}$ based NPK fertilizer recommendation + Biocompost @ $5 \mathrm{t} \mathrm{ha}^{-1}$ for the targeted yield of $16 \mathrm{t} \mathrm{ha}^{-1}$.

\section{Experimental methodology}

The soil was sampled before initiating the experiment, processed and analyzed for available $\mathrm{N}, \mathrm{P}, \mathrm{K}$ following standard procedures of Subbiah and Asija (1956), Olsen et al. (1954), Stanford and English (1949), respectively. The fertilizer doses were calculated for STCR treatments using the existing FPEs developed for surface irrigation and the conventional method of fertilizer application as furnished below:

$\begin{array}{ll}\mathrm{FN} & =0.99 \mathrm{~T}-0.37 \mathrm{SN} \\ \mathrm{FP}_{2} \mathrm{O}_{5} & =0.58 \mathrm{~T}-1.43 \mathrm{SP} \\ \mathrm{FK}_{2} \mathrm{O} & =0.67 \mathrm{~T}-0.25 \mathrm{SK}\end{array}$

For STCR - NPK + FYM @ $12.5 \mathrm{t} \mathrm{ha}^{-1}$ and STCR NPK + Biocompost @ 5 t ha $^{-1}$ treatments, FYM @ 12.5 $\mathrm{t} \mathrm{ha}^{-1}(24 \%$ moisture, 0.53, 0.26, $0.42 \% \mathrm{~N}, \mathrm{P}, \mathrm{K})$ and Biocompost @ 5 t ha $^{-1}$ (33\% moisture, 0.98, 0.56, $0.5 \%$ $\mathrm{N}, \mathrm{P}, \mathrm{K}$ ) respectively were applied in addition to the calculated fertilizer doses from FPEs. Depending on the treatments, a full dose of phosphorous was applied basally during sowing as SSP. Nitrogen and potassium were applied as urea and MOP respectively through fertigation in splits as per stage wise requirement as mentioned in CPG 2020 (Table 1).

A package of practices was done since it is used in common by the TNAU CPG (Horticulture), 2020. During harvest, the yield (bulb and straw) was recorded from each plot. Those samples were processed and analyzed for $\mathrm{N}$ (Humphries, 1956), $\mathrm{P}, \mathrm{K}$ content (Jackson, 1973). By multiplying the dry matter yield with its corresponding nutrient content, the nutrient up- 
take of bulb and straw was computed and added to determine total uptake.

From the experimental data on bulb yield, nutrient uptake, initial soil available $\mathrm{N}, \mathrm{P}, \mathrm{K}$ and fertilizer doses added (Table 2), fertilizer prescription equations were developed for aggregatum onion under drip fertigation by refinement of existing FPEs by the acquisition of protocol on Soil Test Crop Response Correlation as followed by AICRP STCR. These data were statistically analyzed using SPSS software to determine the effect of treatments imposed. The data obtained from treatments $T_{1}, T_{3}$ to $T_{15}$ were utilized for the development of FPEs. To determine the contribution of organics, $T_{6}, T_{7}$ and $T_{11}, T_{12}$ were considered for STCR - IPNS (FYM) and STCR - IPNS (Biocompost) respectively. The computation of basic parameters was done according to the methodology of Ramamoorthy et al. (1967).

\section{Nutrient requirement $\mathrm{NR}\left(\mathrm{Kg} \mathrm{q}^{-1}\right)$}

$\mathrm{Kg}$ of $\mathrm{N} / \mathrm{P}_{2} \mathrm{O}_{5} / \mathrm{K}_{2} \mathrm{O}$ required per quintal of bulb production = Total nutrient uptake of $\mathrm{N} / \mathrm{P}_{2} \mathrm{O}_{5} / \mathrm{K}_{2} \mathrm{O}\left(\mathrm{Kg} \mathrm{ha}^{-1}\right) /$ Bulb yield ( $q \mathrm{ha}^{-1}$ )

.... Eq. 1

2. Percent contribution of nutrients from soil $\mathrm{C}_{\mathrm{s}}(\%)$ Percent contribution of $\mathrm{N} / \mathrm{P}_{2} \mathrm{O}_{5} / \mathrm{K}_{2} \mathrm{O}$ from soil =Total uptake of $\mathrm{N} / \mathrm{P}_{2} \mathrm{O}_{5} / \mathrm{K}_{2} \mathrm{O}$ in control plot $\left(\mathrm{Kg} \mathrm{ha}^{-1}\right) /$ Soil test value of $\mathrm{N} / \mathrm{P}_{2} \mathrm{O}_{5} / \mathrm{K}_{2} \mathrm{O}$ in control plot $\left(\mathrm{Kg} \mathrm{ha}^{-1}\right) \times 100$ .... Eq. 2

\section{Percent contribution of nutrients from fertilizer Cf (\%)}

Percent contribution of $\mathrm{N} / \mathrm{P}_{2} \mathrm{O}_{5} / \mathrm{K}_{2} \mathrm{O}$ from fertilizer =Total uptake of $\mathrm{N} / \mathrm{P}_{2} \mathrm{O}_{5} / \mathrm{K}_{2} \mathrm{O}$ in treated plot $\left(\mathrm{Kg} \mathrm{ha}^{-1}\right)$ - STV of $\mathrm{N} /$ $\mathrm{P}_{2} \mathrm{O}_{5} / \mathrm{K}_{2} \mathrm{O}$ in treated plot $x$ Average $\mathrm{C}_{\mathrm{s}} /$ Nutrient applied through fertilizer $\left(\mathrm{Kg} \mathrm{ha}^{-1}\right) \times 100$

..... Eq. 3

\section{Percent contribution of nutrients from organics Co (\%)}

Percent contribution of $\mathrm{N} / \mathrm{P}_{2} \mathrm{O}_{5} / \mathrm{K}_{2} \mathrm{O}$ from organics = [Total nutrient uptake of $\mathrm{N} / \mathrm{P}_{2} \mathrm{O}_{5} / \mathrm{K}_{2} \mathrm{O}$ in organics treated plot $\left(\mathrm{Kg} \mathrm{ha}^{-1}\right)$ ] -[STV of $\mathrm{N} / \mathrm{P}_{2} \mathrm{O}_{5} / \mathrm{K}_{2} \mathrm{O}$ in treated plot $\mathrm{x}$ Average $\mathrm{C}_{\mathrm{s}}$ ]/Amount of $\mathrm{N} / \mathrm{P}_{2} \mathrm{O}_{5} / \mathrm{K}_{2} \mathrm{O}$ added through organics $\left(\mathrm{Kg} \mathrm{ha}^{-1}\right) \times 100$

..... Eq. 4

\section{Fertilizer prescription equations}

By utilizing the basic parameters, the Fertilizer Prescription Equations were created for aggregatum onion under drip fertigation which could be used to calculate the required dose of fertilizers for a particular soil test value for the soils belonging to Palaviduthi soil series. The FPEs were developed as follows:

$$
\begin{aligned}
\mathrm{FN} & =\frac{\mathrm{NR}}{\mathrm{Cf} / 100} \mathrm{~T}-\frac{\mathrm{Cs}}{\mathrm{Cf}} \mathrm{SN} \\
\mathrm{FN} & =\frac{\mathrm{NR}}{\mathrm{Cf} / 100} \mathrm{~T}-\frac{\mathrm{Cs}}{\mathrm{Cf}} \mathrm{SN}-\frac{\mathrm{Co}}{\mathrm{Cf}} \mathrm{ON} \quad . . \text { Eq. } 6
\end{aligned}
$$

\section{Fertilizer phosphorus}

$$
\begin{aligned}
& \mathrm{FP}_{2} \mathrm{O}_{5}=\frac{\mathrm{NR}}{\mathrm{Cf} / 100} \mathrm{~T}-\frac{\mathrm{Cs}}{\mathrm{Cf}} \times 2.29 \mathrm{SP} \quad . . \mathrm{Eq} .7 \\
& \mathrm{FP}_{2} \mathrm{O}_{5}=\frac{\mathrm{NR}}{\mathrm{Cf} / 100} \mathrm{~T}-\frac{\mathrm{Cs}}{\mathrm{Cf}} \times 2.29 \mathrm{SP}-\frac{\mathrm{Co}}{\mathrm{Cf}} \times 2.29 \mathrm{OP} \\
& . . \text { Eq. } 8
\end{aligned}
$$

\section{Fertilizer Potassium}

$$
\begin{aligned}
& \mathrm{FK}_{2} \mathrm{O}=\frac{\mathrm{NR}}{\mathrm{Cf} / 100} \mathrm{~T}-\frac{\mathrm{Cs}}{\mathrm{Cf}} \times 1.21 \mathrm{SK} \\
& \mathrm{FK}_{2} \mathrm{O}=\frac{\mathrm{NR}}{\mathrm{Cf} / 100} \mathrm{~T}-\frac{\mathrm{Cs}}{\mathrm{Cf}} \times 1.21 \mathrm{SK}-\frac{\mathrm{Co}}{\mathrm{Cf}} \times 1.21 \mathrm{OK} \\
& \quad . \text { Eq. } 10
\end{aligned}
$$

\section{Fertilizer nitrogen}

where $\mathrm{FN}, \mathrm{FP}_{2} \mathrm{O}_{5}, \mathrm{FK}_{2} \mathrm{O}$ are fertilizer $\mathrm{N}, \mathrm{P}_{2} \mathrm{O}_{5}, \mathrm{~K}_{2} \mathrm{O}(\mathrm{Kg}$ $\mathrm{ha}^{-1}$ ) respectively. $\mathrm{NR}$ is nutrient requirement of $\mathrm{N}$, $\mathrm{P}_{2} \mathrm{O}_{5}, \mathrm{~K}_{2} \mathrm{O}\left(\mathrm{Kg} \mathrm{q}^{-1}\right), \mathrm{Cs}$ is percent contribution of nutrients from soil, $\mathrm{Cf}$ is percent contribution of nutrients from fertilizer, Co is percent contribution of nutrients through organics (FYM and Biocompost), T is targeted yield (q ha $\left.{ }^{-1}\right), S N, S P, S K$ are available $\mathrm{N}, \mathrm{P}, \mathrm{K}\left(\mathrm{Kg} \mathrm{ha}^{-}\right.$ $\left.{ }^{1}\right)$ and $\mathrm{ON}, \mathrm{OP}, \mathrm{OK}$ are quantity of $\mathrm{N}, \mathrm{P}, \mathrm{K}$ supplied through organics (FYM and Biocompost) in $\mathrm{Kg} \mathrm{ha}^{-1}$, respectively.

\section{RESULTS AND DISCUSSION}

\section{Bulb yield}

The present study observed that the bulb yield of aggregatum onion (Allium cepa L.) was increased with increasing fertilizer doses of different treatments (Table 2). The remarkably elevated yield was recorded in $T_{10}$ - STCR - NPK + FYM @ 12.5 t - 16 t ha $^{-1}$ (17.58 t ha$\left.{ }^{1}\right)$ followed by $T_{15}\left(16.91 \mathrm{t} \mathrm{ha}^{-1}\right)$ which was on par with $T_{9}$. Subsequently, the greater yield was acquired in $T_{14}$. It was statistically collated with $T_{8}$ and $T_{5}$. The minimal yield was registered in $T_{1}-$ Absolute control (6.56 $\mathrm{t}$ ha$\left.{ }^{1}\right)$. The high targeted yield $\left(16 \mathrm{t} \mathrm{ha}^{-1}\right)$ treatments of STCR - NPK, STCR - NPK + Biocompost @ 5 t ha ${ }^{-1}$ and STCR - NPK + FYM @ 12.5 t ha $^{-1}$ exhibited 6, 13, 16 percent increase in yield respectively over $\mathrm{T}_{2}-$ Blanket recommendation + FYM @ 12.5 t ha $^{-1}$. It was speculated that the inducement of yield in the STCR approach might be due to the consideration of initial soil fertility levels, crop nutrient removal and efficiency 
Table 1. Details of fertigation given as per the stage wise requirement for aggregatum onion following TNAU - CPG (2020)

\begin{tabular}{llllll}
\hline \multirow{2}{*}{ S.No } & Crop stage & $\begin{array}{l}\text { Duration } \\
\text { (DAS) }\end{array}$ & \multicolumn{2}{c}{ Nutrient to be supplied (\%) } & No. of Fertigations \\
& & $\mathbf{N}$ & 10 & 10 & 2 \\
1 & Sowing to establishment & $1-10$ & & 20 & 3 \\
2 & Vegetative & $11-35$ & 30 & 30 & 3 \\
3 & Bulb formation & $36-60$ & 30 & 40 & 3 \\
\hline
\end{tabular}

of nutrients both in soil and added fertilizer. This reason was also supported by Satalagaon et al. (2014) in their study on STCR based fertilizer recommendation for onion through soil application in deep black soil. The main cause for maximum yield in STCR - IPNS over STCR - NPK alone was the slow and effective release of nutrients through organics compared to readily available fertilizer nutrients. Babu et al. (2018) had reported that the escalated yield in drip fertigation than soil application was because of constant nutrient availability during the entire crop growth period. As a whole, the amalgamation of STCR - IPNS approach of fertilizer prescription together with drip fertigation proclaimed the improvement in yield by rising fertilizer use efficiency and timely supply of nutrients than that of adopting the same approach through the conventional method of fertilizer application and surface irrigation even though in similar condition.

\section{Nutrient uptake}

There existed a significant influence of treatments on nutrient uptake, having a range of $\mathrm{N}$ uptake (27.13 to $\left.85.79 \mathrm{Kg} \mathrm{ha}^{-1}\right), \mathrm{P}$ uptake (11.26 to $26.10 \mathrm{Kg} \mathrm{ha}^{-1}$ ), $\mathrm{K}$ uptake (31.47 to $\left.65.11 \mathrm{Kg} \mathrm{ha}^{-1}\right)$. $\mathrm{T}_{10}-\mathrm{STCR}-\mathrm{NPK}+$ FYM @ 12.5 t ha $^{-1}$ - 16 t ha $^{-1}$ exhibited greater N, P, K uptake of $85.79,26.10$ and $65.11 \mathrm{Kg} \mathrm{ha}^{-1}$, respectively. Following $T_{10}, T_{15}$ revealed high nutrient uptake, which was on par with $T_{9}$. The crop had a lesser nutrient uptake in $T_{1}-$ Absolute control. Nitrogen uptake manifested a 3.21 and 1.19 fold increase than $P$ and $K$ uptake, respectively. This pattern of nutrient uptake matched homogeneously with the research on STCR - IPNS based fertilizer prescriptions in Cassava (Suganya et al., 2016), Pearl millet (Ravikiran et al., 2018; Sekaran et al., 2019) and in Bhendi (Ammal et al., 2020)

The greater nutrient uptake in STCR - IPNS treatments could be attributed to the capability of FYM and Biocompost, which created a conducive environment for the crop by enhancing soil properties, nutrient retention and water holding capacity. This would mobilize the unavailable nutrients and also had some positive effects on root growth ensuring improved uptake. The increased nutrient uptake in STCR - NPK + FYM treatments than STCR - NPK + Biocompost treatments might be due to more nutrients from FYM than biocompost thereby minimizing the losses. This might be attributed due to its larger quantity of application. Thangasamy (2016) quantified the nutrient uptake pattern in his study on onion, whose results intimated that basal and soil application of fertilizers was not enough to match the periods of peak nutrient uptake. From the current study, it was pretended to be advantageous to follow STCR - IPNS approach through drip fertigation than through soil application since the nutrients were supplied to the crop at the right time and right method through drip fertigation, the applied nutrients were proficiently taken up by the crop. On the other side, the organics might release the nutrients gradually whose combination had resulted in optimum nutrient uptake.

\section{Response and percent achievement}

By assessing the response, it was obvious that the peak response of $11.02 \mathrm{t} \mathrm{ha}^{-1}$ was attained in $T_{10}$, followed by $T_{15}$ with a response of $10.4 \mathrm{t} \mathrm{ha}^{-1}$. It increased with an increase in yield target. Integrated use of inorganic and organic fertilizers exposed a greater response over inorganic fertilizers alone. This was identical with the findings on STCR - IPNS approach through drip fertigation in hybrid maize (Mohanapriya et al., 2020). In the present case, the percent yield achievement was between 97.7 to 114.7 .

\section{Basic parameters}

The basic parameters viz., nutrient requirement (NR), percent contribution of nutrients from soil $\left(\mathrm{C}_{S}\right)$, fertilizers $\left(\mathrm{C}_{\mathrm{f}}\right)$ and organics $\left(\mathrm{C}_{\mathrm{o}}\right)$ viz., FYM and Biocompost which were quantified from the experimental data are given in Table 3. It was confessed that the nutrient required to bring about one quintal of bulb yield in aggregatum onion was $0.43,0.32,0.45 \mathrm{Kg}$ of $\mathrm{N}, \mathrm{P}_{2} \mathrm{O}_{5}, \mathrm{~K}_{2} \mathrm{O}$, respectively (Fig. 1). The percent contribution of nutrients from soil and fertilizers was reckoned to be 14.01 and 54.57 for $\mathrm{N}, 35.11$ and 50.50 for $\mathrm{P}_{2} \mathrm{O}_{5}, 12.69$ and 70.12 for $\mathrm{K}_{2} \mathrm{O}$, respectively. The $\mathrm{FYM}$ contributed nutrients of $41.02,16.23,41.53$ percent of $\mathrm{N}, \mathrm{P}_{2} \mathrm{O}_{5}, \mathrm{~K}_{2} \mathrm{O}$ respectively. Similarly, the contribution of nutrients from biocompost was $47.98,15.87,49.56$ percent of $\mathrm{N}, \mathrm{P}_{2} \mathrm{O}_{5}, \mathrm{~K}_{2} \mathrm{O}$ sequentially (Fig. 2). 


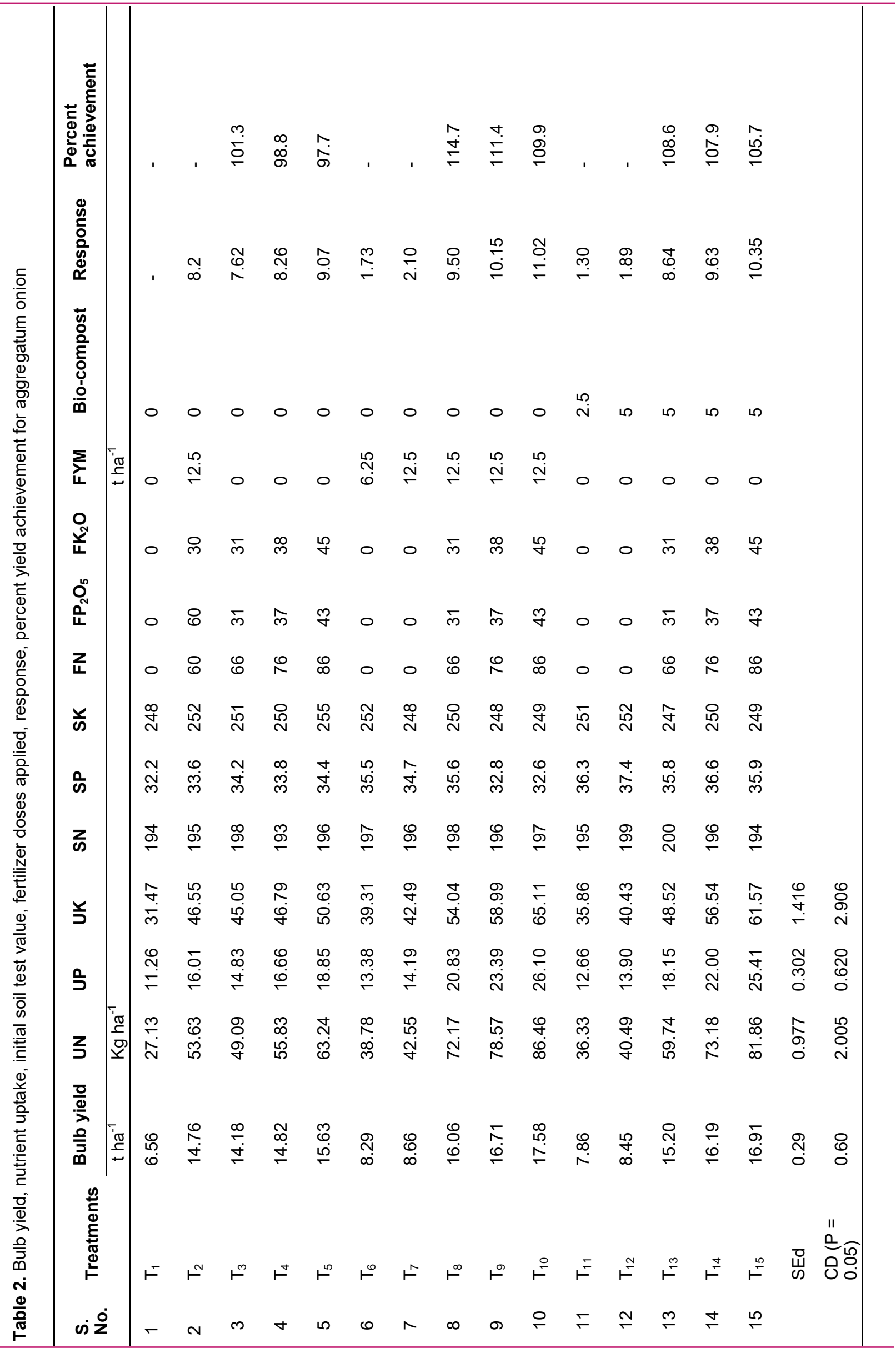




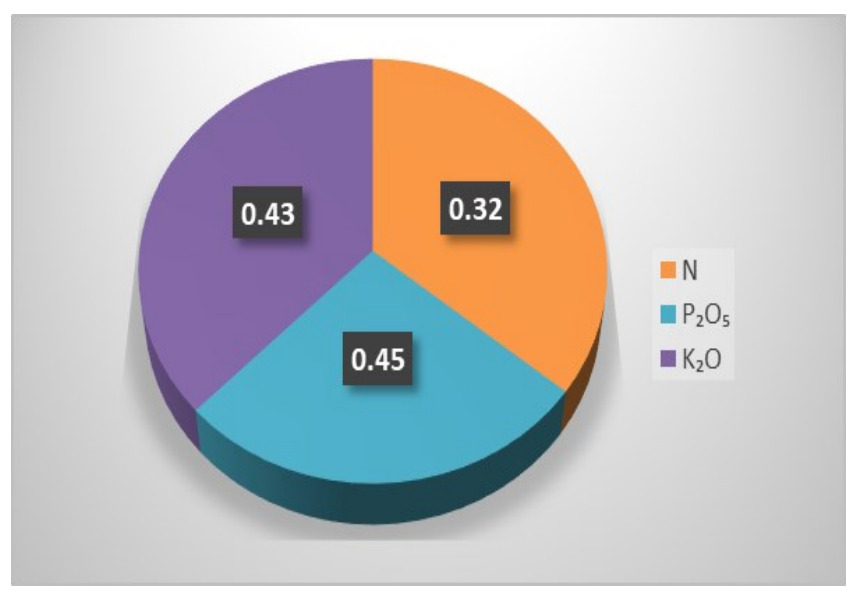

Fig. 1. Nutrient requirement $\left(\mathrm{Kg} \mathrm{q}^{-1}\right)$ of $\mathrm{N}, \mathrm{P}_{2} \mathrm{O}_{5}, \mathrm{~K}_{2} \mathrm{O}$ for aggregatum onion

It was inferred that the percent contribution of $\mathrm{P}_{2} \mathrm{O}_{5}$ from soil was higher to the extent of 2.51 times than $\mathrm{N}$ and 2.77 times than that of $\mathrm{K}_{2} \mathrm{O}$. The contribution of nutrients from fertilizers was more than its contribution from the soil. The data on $\mathrm{C}_{\mathrm{f}}$ showed the order of $\mathrm{K}_{2} \mathrm{O}>$ $\mathrm{N}>\mathrm{P}_{2} \mathrm{O}_{5}$. This trend was in synchronous with the results of STCR-IPNS based fertilizer prescriptions for rice in alfisols (Maragatham et al., 2018) and for cauliflower in inceptisols (Thilagam et al., 2009).

\section{Fertilizer prescription equations for aggregatum onion under drip fertigation}

Using the calculated basic parameters, FPEs were developed for STCR - NPK alone and STCR - IPNS (FYM and Biocompost) for aggregatum onion under drip fertigation as furnished below:

\begin{tabular}{ll}
\hline STCR - NPK + FYM & $\begin{array}{l}\text { STCR - NPK + Biocom- } \\
\text { post }\end{array}$ \\
\hline $\mathrm{FN}=0.79 \mathrm{~T}-0.26 \mathrm{SN}-$ & $\mathrm{FN}=0.79 \mathrm{~T}-0.26 \mathrm{SN}-$ \\
$0.78 \mathrm{ON}$ & $0.88 \mathrm{ON}$ \\
$\mathrm{FP}_{2} \mathrm{O}_{5}=0.63 \mathrm{~T}-1.59 \mathrm{SP}$ & $\mathrm{FP}_{2} \mathrm{O}_{5}=0.63 \mathrm{~T}-1.59 \mathrm{SP}$ \\
$-0.74 \mathrm{OP}$ & $-0.72 \mathrm{OP}$ \\
$\mathrm{FK}_{2} \mathrm{O}=0.64 \mathrm{~T}-0.22 \mathrm{SK}$ & $\mathrm{FK}_{2} \mathrm{O}=0.64 \mathrm{~T}-0.22 \mathrm{SK}$ \\
$-0.75 \mathrm{OK}$ & $-0.86 \mathrm{OK}$ \\
\hline
\end{tabular}

\section{Soil test based fertilizer prescriptions}

The ready reckoner was formulated utilizing the constructed FPEs for a range of soil test values and desired yield target of $17 \mathrm{t} \mathrm{ha}^{-1}$ (Table 4). An estimate from these data showed that when NPK alone was applied with the soil test value of $180: 34: 250 \mathrm{Kg} \mathrm{ha}^{-1}$ of $\mathrm{KMnO}_{4}-\mathrm{N}$, Olsen $\mathrm{P}$ and $\mathrm{NH}_{4} \mathrm{OAc}-\mathrm{K}$, respectively, the fertilizer dose required was $88: 53: 54 \mathrm{Kg} \mathrm{ha}^{-1}$ of $\mathrm{N}$, $\mathrm{P}_{2} \mathrm{O}_{5}, \mathrm{~K}_{2} \mathrm{O}$. It was $50: 35: 25$ and $58: 39: 39 \mathrm{Kg} \mathrm{ha}^{-1}$ of $\mathrm{N}$, $\mathrm{P}_{2} \mathrm{O}_{5}, \mathrm{~K}_{2} \mathrm{O}$ when FYM @ 12.5 t ha $^{-1}$ and biocompost @ $5 \mathrm{t} \mathrm{ha}^{-1}$ was applied along with NPK respectively. The extent of fertilizer saved due to FYM and biocompost application was $38,29 \mathrm{Kg}$ of $\mathrm{N}, 18,14 \mathrm{Kg}$ of $\mathrm{P}_{2} \mathrm{O}_{5}$ and $29,15 \mathrm{Kg}$ of $\mathrm{K}_{2} \mathrm{O}$, respectively.

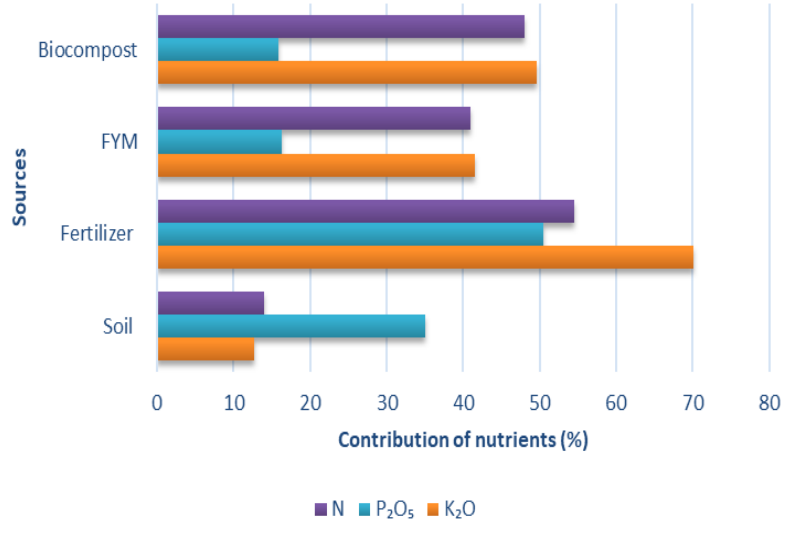

Fig. 2. Contribution of nutrients from soil, fertilizer, FYM, biocompost (\%)

The perusal of nomogram for the targeted yield of $17 \mathrm{t} \mathrm{ha}^{-1}$ and soil test value of $180: 34: 250 \mathrm{Kg} \mathrm{ha}^{-1}$ of $\mathrm{N}$, $\mathrm{P}_{2} \mathrm{O}_{5}, \mathrm{~K}_{2} \mathrm{O}$, sequentially confessed that when FYM and biocompost were applied with NPK, the reduction of fertilizers due to FYM over NPK alone was 43, 35, 54 percent of $\mathrm{N}, \mathrm{P}_{2} \mathrm{O}_{5}, \mathrm{~K}_{2} \mathrm{O}$, respectively and due to biocompost was $33,26,27$ percent of $\mathrm{N}, \mathrm{P}_{2} \mathrm{O}_{5}, \mathrm{~K}_{2} \mathrm{O}$, sequentially. This was concurrent with the findings of Sellamuthu et al. (2019) on STCR - IPNS (FYM) based fertilizer prescriptions through soil application in Big onion. The percent fertilizer reduction due to IPNS over NPK alone increases with an increase in soil nutrient status and decreases with an increase in targeted yield. This decrement may be due to the maintenance of soil fertility by supplying nutrients for a long time and creating favorable soil physical, chemical and biological properties as reported by Suresh and Santhi (2018) for Maize in vertisols of the southern region in TamilNadu. Adekiya et al. (2020) also had the opinion that organic manures also contain both micro and macronutrients, unlike NPK fertilizer that contains only N, P and K. The quality of vegetables can be provoked by integrated nutrient management.

The additional saving of $8,4,14 \mathrm{Kg}$ of $\mathrm{N}, \mathrm{P}_{2} \mathrm{O}_{5}, \mathrm{~K}_{2} \mathrm{O}$, respectively, was generated when FYM was chosen along with NPK instead of biocompost. This might be owing to the large application of FYM. It was obvious from this current study that the use of both organic ma-

Table 3. Basic parameters calculated for developing FPEs for aggregatum onion under drip fertigation

\begin{tabular}{llll}
\hline & $\mathbf{N}$ & $\mathbf{P}_{\mathbf{2}} \mathbf{O}_{5}$ & $\mathbf{K}_{\mathbf{2}} \mathbf{O}$ \\
\hline $\mathrm{NR}\left(\mathrm{Kg} \mathrm{q}^{-1}\right)$ & 0.43 & 0.32 & 0.45 \\
$\mathrm{Cs}(\%)$ & 14.01 & 35.11 & 12.69 \\
$\mathrm{Cf}(\%)$ & 54.57 & 50.50 & 70.12 \\
Co $(\%)-\mathrm{FYM}$ & 41.02 & 16.23 & 41.53 \\
Co $(\%)-$ Biocompost & 47.98 & 15.87 & 49.56 \\
\hline
\end{tabular}


Table 4. STCR based fertilizer recommendation $\left(\mathrm{Kg} \mathrm{ha}^{-1}\right)$ for desired yield target $\left(17 \mathrm{tha}^{-1}\right)$ of aggregatum onion under drip fertigation

\begin{tabular}{|c|c|c|c|c|c|}
\hline $\begin{array}{l}\text { Soil test } \\
\text { value (Kg } \\
\left.\mathrm{ha}^{-1}\right)\end{array}$ & $\begin{array}{l}\text { STCR } \\
\text { Alone }\end{array}$ & $\begin{array}{l}\text { STCR - NPK + FYM } \\
@ 12.5 \mathrm{t} \mathrm{ha}^{-1}\end{array}$ & $\begin{array}{l}\text { Percent reduction } \\
\text { due to IPNS over } \\
\text { NPK alone }\end{array}$ & $\begin{array}{l}\text { STCR- NPK + } \\
\text { Biocompost } \\
\text { @ } 5 \mathrm{t} \mathrm{ha}^{-1}\end{array}$ & $\begin{array}{l}\text { Percent reduction } \\
\text { due to IPNS over NPK } \\
\text { alone }\end{array}$ \\
\hline \multicolumn{6}{|c|}{ Available N } \\
\hline 180 & 88 & 50 & 43 & 58 & 33 \\
\hline 200 & 82 & 45 & 46 & 53 & 35 \\
\hline 220 & 77 & 40 & 49 & 48 & 38 \\
\hline 240 & 72 & 34 & 52 & 43 & 40 \\
\hline 260 & 67 & $30^{*}$ & 56 & 38 & 44 \\
\hline 280 & 62 & $30^{*}$ & 61 & 32 & 47 \\
\hline \multicolumn{6}{|l|}{ Olsen - P } \\
\hline 26 & 66 & 47 & 28 & 52 & 21 \\
\hline 28 & 63 & 44 & 30 & 49 & 22 \\
\hline 30 & 59 & 41 & 31 & 46 & 23 \\
\hline 32 & 56 & 38 & 33 & 43 & 24 \\
\hline 34 & 53 & 35 & 35 & 39 & 26 \\
\hline 36 & 50 & 31 & 37 & 36 & 27 \\
\hline \multicolumn{6}{|c|}{$\mathrm{NH}_{4} \mathrm{OAc}-\mathrm{K}$} \\
\hline 250 & 54 & 25 & 54 & 39 & 27 \\
\hline 270 & 49 & 21 & 58 & 35 & 30 \\
\hline 290 & 45 & 16 & 64 & 30 & 32 \\
\hline 310 & 41 & $15^{\star}$ & 71 & 26 & 36 \\
\hline 330 & 36 & $15^{\star}$ & 80 & 22 & 40 \\
\hline 350 & 32 & $15^{*}$ & 91 & 17 & 46 \\
\hline
\end{tabular}

${ }^{*}$ Maintenance dose (50\% of blanket recommendation - 60:60:30)

nures, i.e., FYM \& Biocompost would have the highest calibre in benefitting the farming community. The use of FYM was economically feasible than biocompost as it was comparatively expensive. Although the cost of biocompost was comparatively higher, it had the potential to minimize not only the application of inorganic fertilizers but also the other organic manures too. This was also reported in the experimental findings of Rahman et al. (2012) in Chilli using biocompost produced from kitchen wastes. So, the biocompost will be the most fitting option to farmers if there is low availability of FYM. Due to the above mentioned benefits of biocompost, the STCR-IPNS based FPEs were also developed for biocompost which could be used by the farmers for aggregatum onion under drip fertigation in Palaviduthi soil series.

\section{Conclusion}

The experimental outcomes showed that the refined fertilizer prescription equations could be used for aggregatum onion ( $A$. cepa L.) under drip fertigation to prescribe specific fertilizer doses for different soil test values and yield targets for Palaviduthi soil series. It would set out as a touchstone to the farming community to effectuate momentous yield and pave the way for an ecologically sound environment and assist in fertilizer saving and nutrient availability. The need of the hour in exhilarating water and nutrient requirement of the crop can be made possible by drip fertigation. Biocompost will be a viable replacement for FYM to the farmers if there is low availability of FYM. Thus, drip fertigation and STCR - IPNS approach brings forth efficient irrigation and balanced fertilization, thereby accomplishing optimum yield in aggregatum onion.

\section{Conflict of interest}

The authors declare that they have no conflict of interest.

\section{REFERENCES}

1. Adekiya, A. O., Ejue, W. S., Olayanju, A., Dunsin, O., Aboyeji, C. M., Aremu, C. \& Akinpelu, O. (2020). Different organic manure sources and NPK fertilizer on soil chemical properties, growth, yield and quality of okra. Scientific Reports, 10(1), 1-9. https://doi.org/10.1038/s41598-02073291-x

2. Ammal, U. B., Prabhu, G. K., Coumaravel, K., Sankar, R. 
\& Dey, P. (2020). Integrated fertilizer prescriptions for bhendi through inductive cum targeted yield model in Bahour soil series (Typic ustropept) of Puducherry. The Pharma Innovation Journal, 9(10), 491-496

3. Babu, V. A., Thingalmaniyan, K. S, \& Natarajan, S. K. (2018). Influence of Drip Fertigation on Yield, Quality parameters and Economics of Aggregatum Onion. Madras Agricultural Journal, 105(1-3)), 1. doi:10.29321/MAJ 201 8.000192

4. Bhasker, P., Singh, R. K., Gupta, R. C., Sharma, H. P., \& Gupta, P. K. (2018). Effect of drip irrigation on growth and yield of onion (Allium cepa L.). J. Spices and Aromatic Crops, 27(1), 32-37. https://doi.org/10.25081/josac.201 8.v27.i1.1012

5. Humphries, E. C. (1956). Mineral components and ash analysis. In Moderne Methoden der Pflanzenanalyse/ Modern Methods of Plant Analysis. Springer, Berlin, Heidelberg. 468-502

6. Jackson, M. (1973). Soil Chemical Analysis." Prentic Hall (India) Pvt. Ltd. New Delhi

7. Maragatham, S., Santhi, R., Sellamuthu, K. M. \& Dey, P. (2018). Yield Targeting for Rice under SRI on Alfisols of Tamil Nadu through Soil Test based Integrated Plant Nutrition System. Int. J. Curr. Microbiol. App. Sci, 7(8), 11341143. https://doi.org/10.20546/ijcmas.2018.708.129

8. Mebrahtu, Y., Tamiru, H. \& Mohammed, A. (2019). Determination of Optimal Irrigation Scheduling for Onion (Allium cepa L.) in Raya Valley, Northern Ethiopia. Results of Natural Resources Management Research.

9. Mohanapriya, G., Gopalakrishnan, M., Santhi, R., Maragatham, S. \& Sritharan, N. (2020). Fertilizer prescription equations for targeted yield of hybrid maize under drip fertigation on alfisol. Journal of Pharmacognosy and Phytochemistry, 9(6), 1350-1355

10. Olsen, S. R. (1954). Estimation of available phosphorus in soils by extraction with sodium bicarbonate (No. 939). US Department of Agriculture.

11. Rahman, M. A., Rahman, M. M., Begum, M. F. \& Alam, M. F. (2012). Effect of bio compost, cow dung compost and NPK fertilizers on growth, yield and yield components of chili. International Journal of Biosciences, 2(1), 51-55

12. Ramadass, S., \& Ramanathan, S. P. (2017). Evaluation of drip fertigation in aerobic rice-onion cropping system. International Journal of Current Microbiology and Applied Sciences, 6(4), 2623-2628. https://doi.org/10.20 546/ijcmas.2017.604.305

13. Ramamoorthy, B., Narasimham, R. L. \& Dinesh, R. S. (1967). Fertilizer application for specific yield targets on Sonora 64 (wheat). Indian farming, 17(5), 43-45

14. Ravikiran, K. B., Santhi, R., Meena, S. \& Sumathi, P. (2018). Refinement of soil test crop response-integrated plant nutrition system based fertilizer prescriptions for pearl millet variety grown under Inceptisol. Madras Agricultural Journal, 105 (4-6), 165-169. (DOI:10.29321/MAJ.2
018.000123

15. Santhi, R., Natesan, R. \& Selvakumari, G. (2002). Soil test based fertilizer recommendation under IPNS for aggregatum onion in Inceptisols of Tamil Nadu. Agropedology, 12, 141-147

16. Satalagaon, G. S., Chandranath, H. T, \& Potdar, M. P. (2014). Response of drill sown onion to nutrient management through soil test crop response (STCR) and soil test laboratory (STL) approach. Karnataka Journal of Agricultural Sciences, 27(2), 232-233

17. Sekaran, U., Santhi, R., Dey, P., Meena, S. \& Maragatham, S. (2019). Validation of soil test and yield target based fertilizer prescription model developed for pearl millet on Inceptisol. Research on Crops, 20(2), 266-274. DOI:10.31830/2348-7542.2019.039

18. Sellamuthu, K.M \& Santhi, R. \& Subramaniam, S.Maragatham \& Dey, P. (2019). Balanced Fertilizer Prescription for Big Onion through Inductive Cum Targeted Yield Model on an Alfisol. Madras Agricultural Journal, 106 (10-12). doi:10.29321/MAJ 2019.000322

19. Solanki, R. M., Malam, K. V., Vasava, M. S. \& Chhodavadia, S. K. (2020). Influence of rabi onion (Allium cepa L.) to levels and application schedule of soluble fertilizers under drip irrigation. The Pharma Innovation Journal, 9(9), 176-181

20. Stanford, G. \& English, L. (1949). Use of the flame photometer in rapid soil tests for $\mathrm{K}$ and $\mathrm{Ca}$. Agronomy Journal, 41(9), 446-447

21. Subbiah, B. V. \& Asija, G.L (1956). A rapid procedure for estimation of available nitrogen in soil. Curr. Sci., 25, 259260

22. Suganya, S., \& Manickam, S. (2017). Soil Test Crop Response based Integrated Plant Nutrient Supply for Cassava in a Typic Rhodustalf of Tamil Nadu for Sustainable Livelihood. Journal of Root Crops, 42(2), 39-43

23. Suresh, R., \& Santhi, R. (2018). Validation of soil test and yield target based fertiliser prescription model for hybrid maize on Vertisol. Int. J. Curr. Microbiol. App. Sci, 7(9), 2131-2139. https://doi.org/10.20546/ijcmas.2018.709.261

24. Thangasamy, A. (2016). Quantification of dry-matter accumulation and nutrient uptake pattern of short day onion (Allium cepa L.). Communications in Soil Science and Plant Analysis, 47(2), 246-254. https://doi.org/10.1080/00 103624.2015.1118116

25. Thilagam, V. K., \& Natesan, R. (2009). Fertilizer prescription equations for desired yield targets of cauliflower under integrated plant nutrient system based on targeted yield model. Agricultural Science Digest, 29(4), 250-253.

26. Vijayakumar, M., Santhi, R., \& Jalaluddin, S. M. (2017). Refinement of fertilizer recommendation based on Soil Test Crop Response technology for rice under System of Rice Intensification. Journal of Applied and Natural Science, 9(2), 855-859. https://doi.org/10.31018/ jans.v9i2. 1286 